\title{
ÉRTÉKET NEM TEREMTÓ FOLYAMATOK FELTÁRÁSA VSM MÓDSZER ALKALMAZÁSÁVAL EGY KIS VÁLLALKOZÁS GYÁRTÓRENDSZERÉNEK ESETTANULMÁNYÁN KERESZTÜL.
}

\section{EXPLORING NON-VALUE-CREATING PROCESSES USING THE VSM METHOD THROUGH A CASE STUDY OF A SMALL ENTERPRISE'S MANUFACTURING SYSTEM.}

\author{
Thalmeiner Gergö ${ }^{1}$, Harmat Vanda ${ }^{2}$, Gáspár Sándor ${ }^{1}$ \\ ${ }^{1}$ Pénzügymenedzsment és Controll Tanszék, Gazdaság és Társadalomtudományi Kar, Szent István Egyetem, \\ Magyarország \\ ${ }^{2}$ Szervezeti Magatartás Tanszék, Gazdálkodástudományi Kar, Budapesti Corvinus Egyetem, Magyarország
}

\author{
Kulcsszavak: \\ lean \\ vsm \\ termelékenység \\ folyamatmenedzsment \\ veszteség feltérképezés \\ Keywords: \\ lean \\ vsm \\ productivity \\ process management \\ loss mapping
}

\section{Összefoglalás}

Hazánk egyik jelentôs problémája a termelékenység alacsony szintje. Ez az alacsony szint pedig kiemelkedően jellemző a kis- és közép vállalkozások körében. A legtöbb régiós és a nyugat-európai országokban ezen méretü vállalkozások átlagos termelékenységi szintje magasabb, mint hazánkban. A jelenlegi és várhatóan a közeljövőben is jelen lévő munkaeröhiányos környezet a vállalkozásokat kihívás elé állítja. A munkaerő megtartásához hozzájáruló bérnövekedés megteremtése hosszútávon kizárólag a termelékenység növelésével biztosítható. Ha a szervezet nem képes a termelékenység növelésének elérésére, alul marad mind a hazai, mind pedig a nemzetközi-globális versenyben.

A hazai kis- és középvállalkozások termelékenységének és a versenyképességének növelésében kulcs elem lehet a modern gazdálkodásszervezési és menedzsment rendszerek, például a lean menedzsment alkalmazása. A lean menedzsment az egyik leggyakoribb és leghatékonyabb folyamatszervezési módszer, illetve paradigma, amelyet a szekunder és tercier szektorokban bevált módon alkalmaznak, olyannyira, hogy a lean szemléletre épülő menedzsment módszerek alkalmazása sok esetben versenykritériummá, és alapvetővé vált.

Kutatásunkban egy CNC fémforgácsoló KKV folyamatait, azon belül is a CNC marási és esztergálási folyamatok értékfolyamat feltérképezését készítjük el. Ez az értékfolyamat feltérképezési módszer lehetőséget kínál arra, hogy az ágazatban felmerülő veszteségek

\footnotetext{
${ }^{1}$ Kapcsolattartó szerző. Tel.: +36 202466555

E-mail cím: thalmeinergergo@gmail.com
} 
megismerhetővé és kiküszöbölhetövé váljanak. A térkép elkészítésén keresztül megvalósítható a mudákat termelő folyamatok szemléltetése és ezáltal az átfutási idő csökkentése, illetve a termelékenység növekedése. Vizsgálatunk során egy CNC technológiával megmunkált fémalkatrészeket gyártó vállalkozás példáján keresztül mutatjuk be a módszer gyakorlati megvalósulását.

\section{Abstract}

One of the major problems in Hungary is the low level of productivity. This low level is particularly noticeable among small and medium-sized enterprises. In most regional and Western European countries, the average productivity level of enterprises of this size is higher than in Hungary. The current and expected shortage of labor in the near future poses a challenge to businesses. Creating wage growth that contributes to retaining the workforce can only be achieved in the long run by increasing productivity. If an organization is unable to achieve productivity gains, it will fall short of both domestic and international-global competition.

The application of modern management and management systems, such as lean management, can be a key element in increasing the productivity and competitiveness of Hungarian small and medium-sized enterprises. Lean management is one of the most common and effective process organization methods and paradigms used in the secondary and tertiary sectors, so much so that the use of lean-based management methods has in many cases become a competitive criterion and fundamental.

In our research, we prepare the value process mapping of a CNC metal cutting SME, including the value process of CNC milling and turning processes. This value process mapping method offers an opportunity to make losses in the industry

become known and preventable. Through the preparation of the map, it is possible to illustrate the processes that produce mud and thus reduce the lead time and increase productivity. In the course of our study, we present the practical implementation of the method through the example of a company manufacturing metal parts machined with CNC technology..

\section{Bevezetés}

A XXI. század globalizált világgazdaságában a vállalatok nagyobb hangsúlyt fektetnek azoknak a vezetési rendszereknek a használatára, amelyek döntéstámogató információkat tartalmaznak és segítik a menedzsment munkáját [18]. A különböző modern vezetési filozófiák közül jelentős hangsúlyt képvisel a lean menedzsment, amely az egyik legelterjedtebb menedzsment filozófia.

\section{Szakirodalmi áttekintés}

A lean szemlélet segítségével meg lehet határozni, hogy mi az érték. Csakis a végfelhasználó az, aki eldöntheti, hogy mi számít értéknek, és csak akkor lehetséges érdembe értékről beszélni, ha egy adott termék az adott áron és idóben kielégíti a vevő igényeit [17]. Az értéket pedig mindig gyártó illetve termelő teremti meg (Shigeo, 1989). A lean manufacturing nem csak egy gyártási rendszer, hanem egy olyan gyártási filozófia és kultúra, amely holisztikusan jelenik meg a szervezeti funkciók között és ebben a filozófiában a kultúra fontosabb szerepet játszik, mint a technikai háttér [19].

Losonci D. (2017) szerint a lean menedzsment célja a pazarlás mindennemű formájának eltüntetése, megszüntetése. A pazarlásoktól mentes folyamtok gyorsabbak, megbízhatóbbak, és jobb minőséget eredményeznek, de a legfontosabb, hogy alacsonyabb költségek mellett lehetséges a müködés. A kínálati oldal pazarlásoktól mentes folyamatai a keresleti oldalon magasabb vevő értéket jelent, illetve teremt [11].

A lean szemlélet segítségével optimális sorrendbe lehet állítani azokat a műveleteket és folyamatokat, amelyek értéket teremtenek, és ezeket a megfelelő időben, a megfelelő helyen, a megfelelő mennyiségben, megszakítás nélkül egyre hatékonyabban lehet elvégezni (Vörös, 2010). A lean szemlélet nem állhat meg egy cég határánál, hanem azon tovább kell terjednie a teljes ellátási láncra, illetve adott üzletág-iparág teljes vertikumára [17]. A lean menedzsment a gazdaságos rendszer és termelés kialakítása mellett, a folyamatos fejlődés és jobbítás szemléletének bevezetésével nagyon kiemelt szerepet képvisel a szervezeti kultúra és az alkalmazottak gondolkodásának formálásában [10]. 
James és munkatársai öt darab alapelvet határoztak meg a lean menedzsment hatékony működésével szemben, amelyek a következőek: az érték meghatározása, értékfolyamat azonosítása, áramlás létrejötte az értékteremtő lépések mentén, húzóelv alkalmazása, tökéletesítés, folyamatos fejlesztés [17].

A 21. században nagyon sok szervezet alkalmazza sőt, sok iparágban versenykritériumként is megjelenik a lean menedzsment alkalmazása illetve implementálása a gazdálkodás szervezési folyamatok müködtetése során, de nagyon kevés esetben történik meg a filozófiának az implementálása a termék fejlesztési folyamatok esetében. Csak azon szervezetek válhatnak teljes mértékben értékteremtő szervezetté, amelyek képesek a termék fejlesztésre is alkalmazni lean filozófiát [12].

A lean menedzsment hatékony implementálását nem az iparág, hanem a folyamatok jellege határozza meg. Bármely iparágban lehet sikeres az implementálás, azonban az eszközöket a szektor és a szervezet sajátosságaihoz kell igazítani, valamint a szervezeti kultúra részévé kell válnia a filozófiának. A lean átalakítások hatékonysága érdekében, szükség van az új szemléletet befogadni már kész szervezeti kultúrára [3]. A szakirodalom nem ad egyértelmű választ arra, hogy mi tekinthető „ideális lean kultúrának”. A probléma feloldásához abból a széleskörüen elfogadott felismerésből lehet a megoldáshoz jutni, hogy a lean menedzsment alapját és mai napig a legjobb példáját a Toyota rendszere szolgáltatja. Ennek alapján a Toyota vállalati kultúráját lehet az „ideális lean kultúrának” nevezni [16].

A lean menedzsment bevezetése és a lean rendszer múködése ugyanannak a tevékenységsorozatnak különböző időbelileg elkülönült fázisait jelentik. A különböző fázisokban az egyes tényezők különböző hangsúlyokat kapnak, például az első fázisban a tanulás, az új eszközök, módszerek elsajátítása, valamint a dolgozói ellenállás kiküszöbölése, és még sok más, jóval nagyobb szerepet játszanak, mint a mindennapi múködés során, amikor inkább a már megtanultak rögzítése, leírása, szabályozása, finomítása áll a középpontban. Tehát teljesen más eszközökre és módszerekre van szükség a beveztéskor és a müködtetéskor [1].

\subsection{Muda}

A muda, veszteséget jelent, azaz minden olyan emberi tevékenységet, amely erőforrást használ fel, de nem teremt értéket. Annak ellenére, hogy a vevő csak azért hajlandó fizetni, ami számára értéket jelent, a folyamatok elemeinek (tevékenységek, müveletek, müveletelemek, mozdulatok) jelentős része nem termel értéket. Taaichi Ohno eredetileg hét darab muda típust azonosított a fizikai termelésre általánosan jellemző vesztségekről. A hét darab veszteség a következő: túltermelés, várakozás, felesleges szállítás, technológiai veszteség, készletek, felesleges mozgások, selejt termelése [13].

\subsection{Just In time}

A lean szemlélet egyik alapvető eleme és módszere a Just in Time rendszer. A termelési folyamatok centrumába helyező integrált rendszerfejlesztés sajátos irányzata a Just in Time elv, illet ezen múködési filozófia, amely egyben a gyakorlatban múködő sajátos termelésirányítási rendszer is [9]. A fejlett gazdaságokban van egy sajátos trend, a gyártásmélység csökkenése. Ez azt jelenti, hogy a gyártók egyre inkább csak a fó tevékenységen belüli gyártási folyamatok, gerincfeladatira koncentrálnak és a különböző kiegészítő jellegű gyártási feladatokat átadják a beszállítóknak, vagyis kiszervezik. Ennek a trendnek az egyik elősegítője és lehetővé tétele a termelékenység megtartásával, a Just in Time rendszer volt, és még jelenleg is az [5].

\subsection{Value Stream Mapping}

A VSM (Value stream mapping) vagyis értékfolyamat térkép egy stratégiai eszköz, amely által azonosíthatóvá válnak a veszteségek. Az értékfolyamat térképet több szakirodalom értékáram térképnek szokott nevezni. A Toyotánál anyag és információáramlási diagram néven ismert módszer egy változata [7].

A VSM segítségével a következőket lehet vizsgálni:

- Az értékfolyamat térképezés alkalmazásával láthatóvá válik az anyag és információáramlás teljes folyamata, a beszállítótól kezdve egészen a vevőig. 
- Észre lehet venni olyan veszteségeket, amelyek az egyes folyamatokra koncentrálva nem lennének láthatók.

- A termelési rendszert jobban és mélyebb szinteken lehet megismerni és vizsgálni

- Szigetszerű alkalmazás helyett lehetővé válik a lean eszközök strukturált alkalmazása

- A folyamatokat az értékteremtés szemszögéből lényeges sorrendben lehetséges ábrázolni.

- Könnyebbé válnak a fejlesztési projektek megvalósítási sorrendjének kialakítása illetve meghatározása.

- Egyszerúbbé és könnyebbé válik a kommunikáció a termelési rendszerrel kapcsolatos kérdésekben [7].

Az értékfolyamat térképezés sikeresen alkalmazható a termelési és tervezési folyamatok feltérképezésére [4]. Viszont a szolgáltatási folyamatok feltérképezése során is sikeresen lehet implementálni, elsősorban a gyakran ismétlődő repetitív adminisztratív folyamatok ábrázolására, vizsgálatára, elemzésére és fejlesztésére [6].

A térképezés lépései a következők

- Termék család kiválasztása

Egy adott üzemben a legtöbbször számos terméktípust gyártanak, melyek egymástól teljesen eltérő folyamatokon, illetve múveleteken haladnak, áramlanak át. Ahhoz hogy egy átlátható térképet megvalósíthassunk, az szükséges, hogy bizonyos kompromisszumokat kössünk [14]. Az első ilyen kompromisszum, hogy egy térképen nem lehet ábrázolni többet egy termékcsaládnál, mert a térkép átláthatatlanná válik, és akkor már nem tudja betölteni a feladatát [2].

Általánosan elfogadott ökölszabály, hogy azokat a termékeket lehet egy termékcsaládba sorolni, amelyekre az jellemző, hogy: az egyes müveleteken belül a rájuk fordított munkamennyiség maximum 30\%-ban tér el egymástól, valamint közel 80\%-ban ugyanazokon a müveleteken haladnak keresztül [8].

- Jelenállapot térkép készítése

Miután meg lett határozva az ábrázolandó termékcsalád, szükségessé válik az információk begyưjtése a jelen állapot feltérképezéséhez. A térképezés a beszállítótól a vevőig tart, de a fő fókusz a termelési folyamatokra helyeződik. A beszállítókat és a vevőket is csak ezekhez való kapcsolódásuk miatt lehet ábrázolni. Itt is igaz az, mint a lean módszerek alkalmazására általában igaz, hogy itt sem kell annak az elsődleges célnak lenni, hogy az információk 100\%-t már a jelenállapot felvétele során megszerezzük. Ennél a lépésnél kiemelt szerepet játszik, hogy a térképezés egyetlen célja a fejlesztés lehessen, mert önmagában a térkép elkészítésével nem tudjuk növelni a hatékonyságunkat [15].

- Problémák megjelölése

Ha már meg van rajzolva a jelenállapot térkép, akkor következhet a térképen a problémák ábrázolása. Ezek a problémák azok, amelyek akadályozzák a hatékony anyag és információáramlást, illetve ezek a problémák azok, amelyek eltérnek az ideális termelési rendszertől és az elvárt állapottól.

- Jövőállapot térkép készítése

Ha már lehet látni, hogy hogyan, múködik a termelési rendszer, és azt is, hogy mely fő problémákkal kell szembenézni, akkor el lehet kezdeni a jövőállapot térkép elkészítését. Ez azt fogja megmutatni, hogy milyennek, kell lennie a termelési rendszernek, hogy hatékonyan müködjön a rendszer.

- Megvalósítás

A legalaposabban megrajzolt térkép sem lesz aktuális túl sokáig, mert folyamatok napról napra változhatnak. Ez az elsődleges oka, hogy a jövőállapot-térkép megrajzolása után a lehető leghamarabb neki kell kezdeni az akciólisták megírásának, és a megvalósítást is rövid időn belül meg kell kezdeni. A szokásos feladat- felelős- határidőn kívül meg kell határozni az adott feladatok célját és azoknak a mérési módszereit is [8].

\section{Eredmények}

CNC fémforgácsolás értékfolyamat feltérképezéséhez szükséges jelöléseket és azok megnevezéseit az 1. ábra szemlélteti 


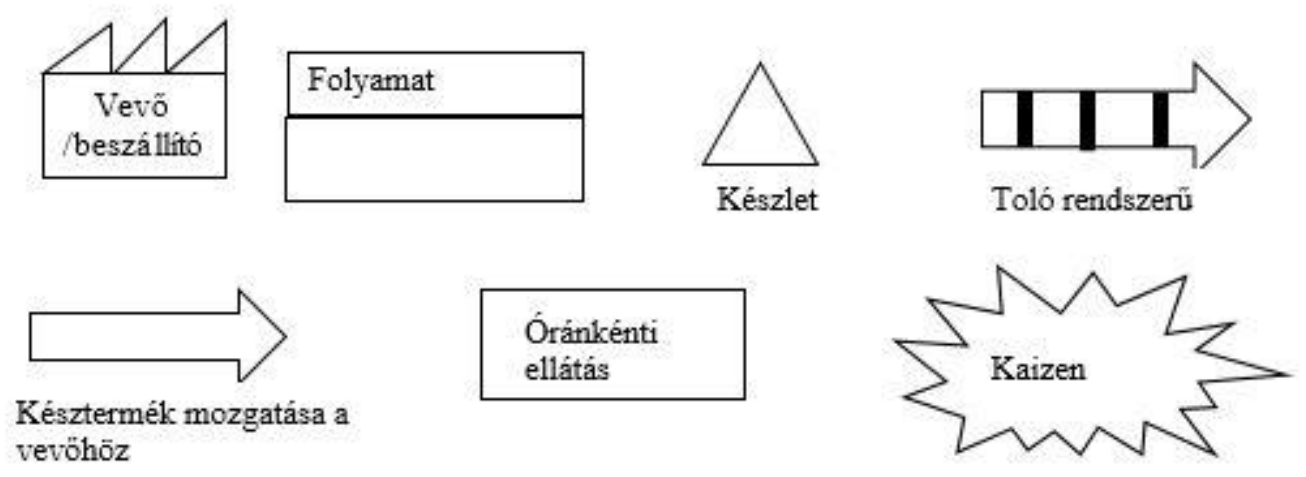

\author{
1. ábra: Jelmagyarázat \\ Forrás: Saját szerkesztés, 2020
}

Fontos továbbá meghatározni az értékfolyamat térképeken szereplő rövidítéseket, amelyek a következők:

- Ciklusidő (CT-cycle time): Egy termék elkészítésnek időszükséglete.

- Átállási idő (CO-change over time): Gépek átállási ideje egy másik munkafolyamatra egy adott technológián belül. (Például A CNC gépek átállítása egy másik termék gyártására)

- Létszám: Az adott folyamatba résztvevő alkalmazottak száma.

- Termelési idő: Ez az időtartam már magába foglalja a műszak hosszából levont szüneteket és egyéb tervezett megállásokat, leállásokat.

A térképek alján azt fogjuk jelezni, hogy az egyes folyamatok illetve technológiáknak mennyi az értékteremtő ideje. Mivel a cég nem igazán tudta ezt az időt meghatározni ezért csak megközelítő értékeket fogunk alkalmazni az értékteremtő idő meghatározására. Továbbá a folyamatok, illetve technológiák között pedig azt fogjuk jelezni, hogy mennyi időt kell várnia egy-egy adott technológiának, hogy a másik technológia elkészülhessen. Ez az idő már tartalmazza az értékteremtő időket is. A maradék várakozás az alkalmazottak felesleges tevékenységeiből, az előre tervezett elvégzendő idő kicsúszásából, információ és anyag hiány miatt történik .Ezek a számok átlagolva és becsülve vannak egy-egy munkálatra levetítve az üzemvezetés segítségével.

Az értékfolyamat térképeken a különböző alapanyagokat és a készterméket jelöljük. Amelyek jelen esetben a következők: alumínium, műanyag, csavar, késztermék. Ezeknek a térképeken való jelölése sorrendben a következő: a, m, cs, k, amelyeknek értéke különböző folyamatok, illetve megmunkálások során változik. Az elemzés során havi rendelési tétel mennyiséget vizsgáltuk, amelyet alacsony szórással rendelkező heti átlagos mennyiségként tüntettünk fel az érték folyamattérképeken, mint végső output. A szervezet készletezési stratégiáját megvizsgálva megállapítható, hogy a havi készletezést, 2 hetente történő beszállítással biztosították, és ez még biztonsági készleten kívül magas felhalmozódást is jelent. A termelés illetve kivitelezés ütemezése manuális módszerrel múködik a vállalkozásnál, tehát a üzemvezetés felügyeli és biztosítja a szükséges készleteket és alakítják ki a termelési-kivitelezési utasításokat.

\title{
3.1. Jelenállapot elemzése
}

A jelenállapot térképen (2. ábrán) látható, hogy 5 munkafolyamatra volt bontható a tevékenység. Ezen folyamatok az alkatrész gyártás során strukturáltak voltak. Láthatóvá vált, hogy több nem értékteremtő ellenőrzési folyamat is volt a rendszerben.

A teljes átfutási idő 20520 perc volt, amely magába foglalta az állási és kényszervárakozási, illetve egyéb nem értékteremtő és értékteremtő folyamatokat. A kifejezetten értékteremtő idő összesen: 250 perc volt.

A nem értékteremtő folyamatok közül jelentős hányadot képvisel a többszörös ellenőrzési folyamtok megléte, a készleten állási idő és a raktározási tevékenység. A lean szemlélet bevezetése 
előtt a késztermék előállítása érdekében alkalmazott létszám 30 fő volt, amely az üzemvezetők elmondása alapján átlagos létszámnak számít a hazai versenytársakhoz mérten.

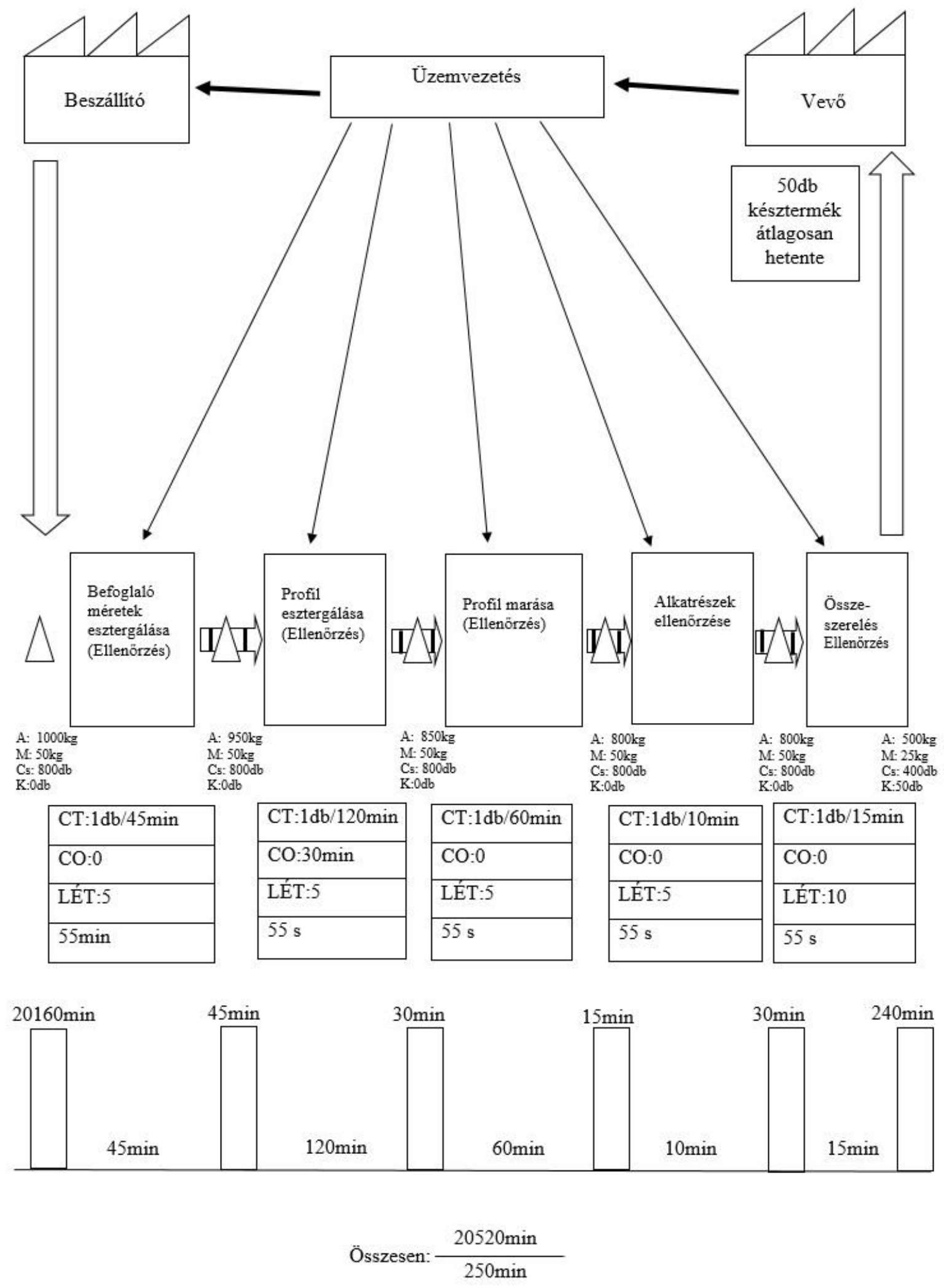

2. ábra: Jelenállapot feltérképezése

Forrás: Saját szerkesztés, 2020 
A 3. ábrán feltüntetett észrevételek közül az első a készletek kezelésével kapcsolatos. A lean egyik alapelve, hogy ha lehetséges, akkor vonjunk össze folyamatokat a köztes készlet megszüntetése érdekében. Véleményünk szerint jelen esetben a készletek mennyisége nem indokolt a termelés folyamatos és biztonságos működéséhez, ezért ez egy olyan muda-ként jellemezhető amely nem teremt értéket és mind likviditási mind helykihasználási problémákat okoz. A beszállítók által történő készlet feltöltések 2 hetente történnek de ezek nem indokoltak.

A második észrevétel kétszeres esztergálási folyamatnak a megléte, amely két folyamatból tevődik össze. Egyrészről megtörténik a munkadarab befoglaló méreteinek nagyrészében való méretre való megmunkálása. Ezt követően egy leállási folyamat következik mely során a terméket egy következő CNC esztergagéphez mozgatják. Ezen folyamat során a terméken teljes mértékben elvégzik az esztergálási műveleteket. Az átmérős munkaműveletek teljes mértékben megtörténnek.

Harmadik észrevett probléma az volt, hogy a CNC megmunkálásokat követô ellenőrzési folyamat egy teljes folyamatként definiálható, mely nem értékteremtő tevékenységnek tekinthető. Ez azért is kiemelendő, mert amint az a térképen is feltüntetésre került, az egyes munkafolyamatokat követően, a munkájukra igényes munkatársak csak is úgy adják tovább a munkadarabot a következő munkafázishoz, hogy azt ellenőrzik. Továbbá, a munkadarabok a műanyagelemek összeszerelését átadás és csomagolási folyamatok előtt egy teljes minőségellenőrzésen mennek át, amin a befoglaló méretek és türési paramétereire kerül sor. Ezért a kész munkadarab ellenőrzési folyamat, mint beékelődő teljes értékű tevékenység egy ténylegesen nem értékteremtő folyamatként magyarázható.

Utolsó észrevételként megfigyeltünk egy termelés szervezés szempontjából nem jelentős problémát, ugyanakkor likviditás szempontból nagyon hangsúlyosnak értelmezhető. A heti ciklus gyártási folyamatnak a vége és a termékek szállítási ideje egy nem jól összehangolt folyamat, mely során a kész termékek egy teljes hétvégét állnak raktáron. Ebből kifolyólag nem kerülnek a megrendelőhöz, ezáltal a pénzügyi ellentételezés is időben kitolódik mivel havi szinten kész termék leszállításától függően több ciklusban is történik a tranzakció. 


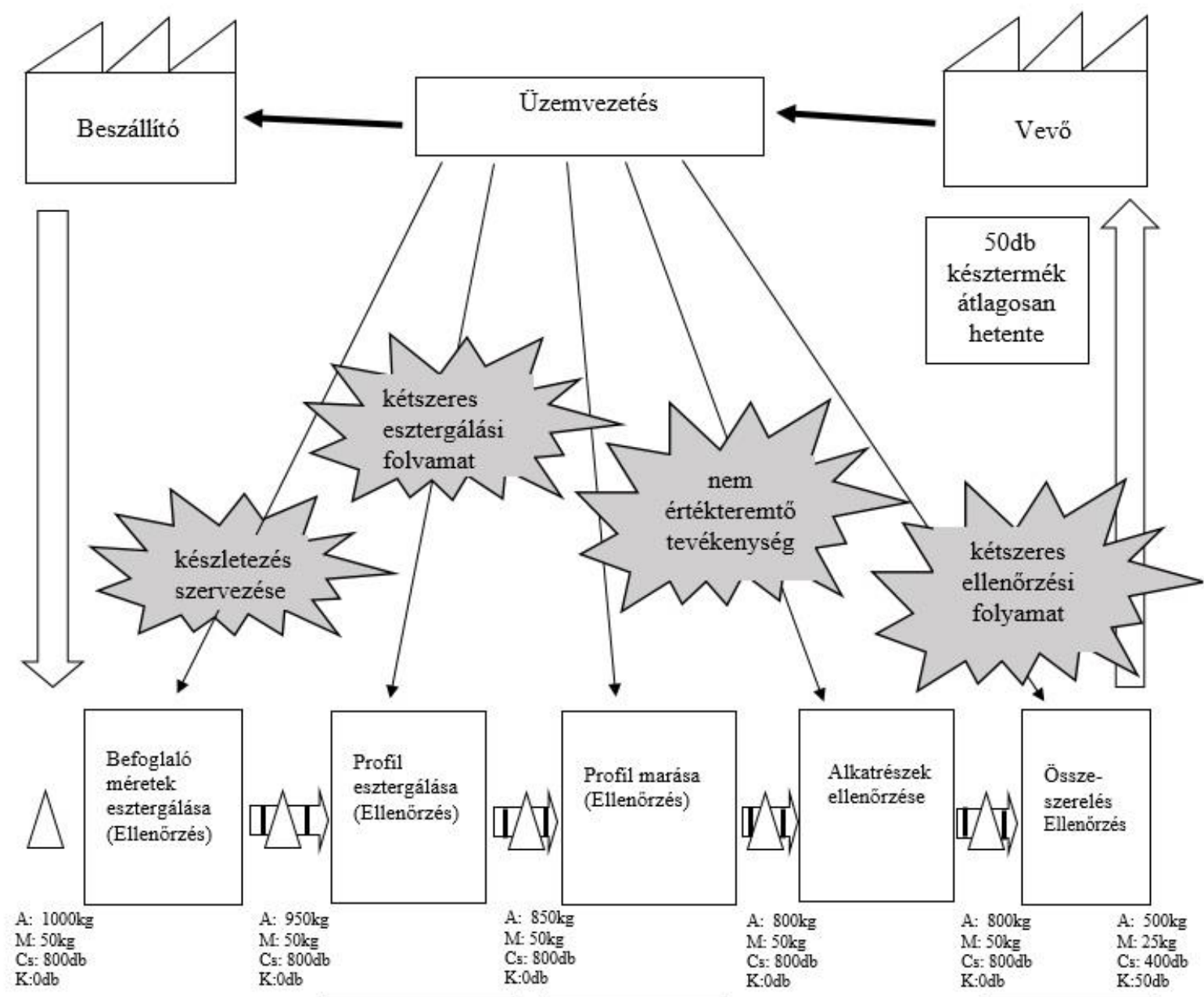

\begin{tabular}{|l|}
\hline CT: $1 \mathrm{db} / 45 \mathrm{~min}$ \\
\hline CO: 0 \\
\hline LÉT:5 \\
\hline $55 \mathrm{~min}$ \\
\hline
\end{tabular}

\begin{tabular}{|l|l|}
\hline $\mathrm{CT}: 1 \mathrm{db} / 120 \mathrm{~min}$ & $\mathrm{CT}: 1 \mathrm{db} / 60 \mathrm{~min}$ \\
\hline CO:30min & \\
\hline LÉT:5 & CO:0 \\
\hline $55 \mathrm{~s}$ & LÉT:5 \\
\hline $55 \mathrm{~s}$ \\
\hline
\end{tabular}

\begin{tabular}{|l|}
\hline CT:1db/10min \\
\hline CO:0 \\
\hline LÉT:5 \\
\hline $55 \mathrm{~s}$ \\
\hline
\end{tabular}

\begin{tabular}{|l|}
\hline CT:1db/15min \\
\hline CO: 0 \\
\hline LÉT:10 \\
\hline $55 \mathrm{~s}$ \\
\hline
\end{tabular}

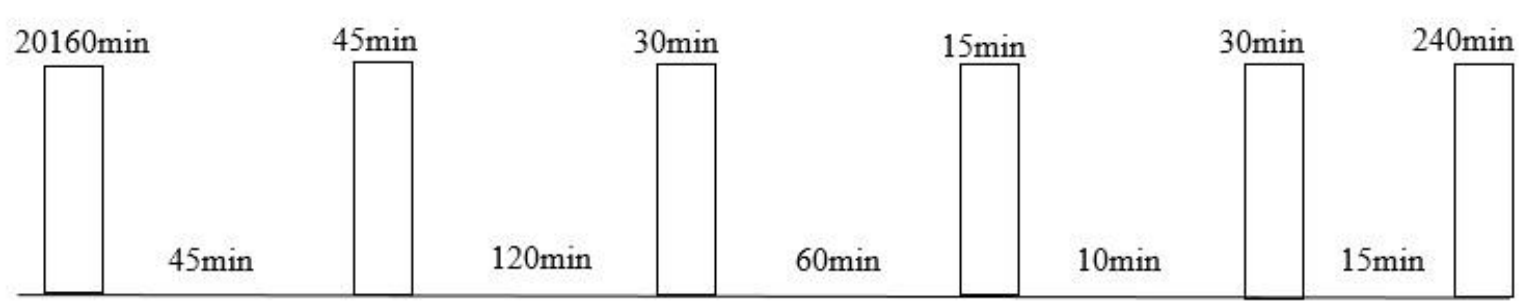

Összesen: $\frac{20520 \mathrm{~min}}{250 \mathrm{~min}}$

3. ábra: Mudák jelölése

Forrás: Saját szerkesztés, 2020 
A 4. ábra a szemlélteti a jövőállapot térképet, melynek jelölései és formális kinézete ugyanaz lesz mint a jelenállapot térképnek csak itt már az az állapot lesz ábrázolva, ahogy át lett szervezve a rendszer, vagyis itt már az üzem hatékonyabb és termelékenyebb állapota látható.

Az első és második problémára a leghatékonyabb megoldást a készletezési- folyamatok átgondolt átszervezése nyújtotta. A beszállítókkal sikerült egy előnyös megállapodást kötni amely során a két hetes alapanyagbeszállítási ciklust sikerült heti szintű kisebb tétel mennyiségü ciklussá átalakítani. Ez mind likviditásban mind helykihasználtságban nagy előrelépés a cég számára, amely a folyamatos gyártást nem veszélyeztetve hatékonyabbá tette a termelés és a szervezet múködését.

A jelenállapot térképen feltüntetett két esztergálási folyamatot egy dolgozó javaslat a (kaizen) segítsége által sikerült összevonni, mely során a szervezet nyitottá vált eszköz beruházásra. A technológiai fejlesztés során több ellenorsós CNC esztergapad beruházásra került sor, ennek hatására már a CNC esztergálási folyamatot már nem kell megszakítani, a folyamat, egy tevékenységként kezelhető. Ennek az előrelépésnek köszönhetően az értékteremtő folyamat átfutási ideje csökkent, a várakozási idő megszűnt

Az utolsó problémára az ellenőrzésnek, mint nem értékteremtő tevékenységnek a beintegrálása a legjobb megoldás. Mint ahogy már az előbbiekben is említésre került az igényes munkavégzés során a munkadarabok minden egyes tevékenységet követően ellenőrzésre kerülnek. Ennek a filozófiának a támogatására, valamint terjesztésére a szervezeten belül a vezetőségnek koncentrálnia kell hiszen ezzel az utólagos ellenőrzési tevékenységek megszüntethetőek illetve a selejtek száma csökkenthető.

Azáltal hogy a értékteremtő folyamatok időben csökkentek a heti termelési ciklus már lehetővé teszi hogy adott tárgy héten a kész termékek szállítása a megrendelő felé megtörténhessen. Ezáltal a likviditás nő és a készletezési idő csökken. 

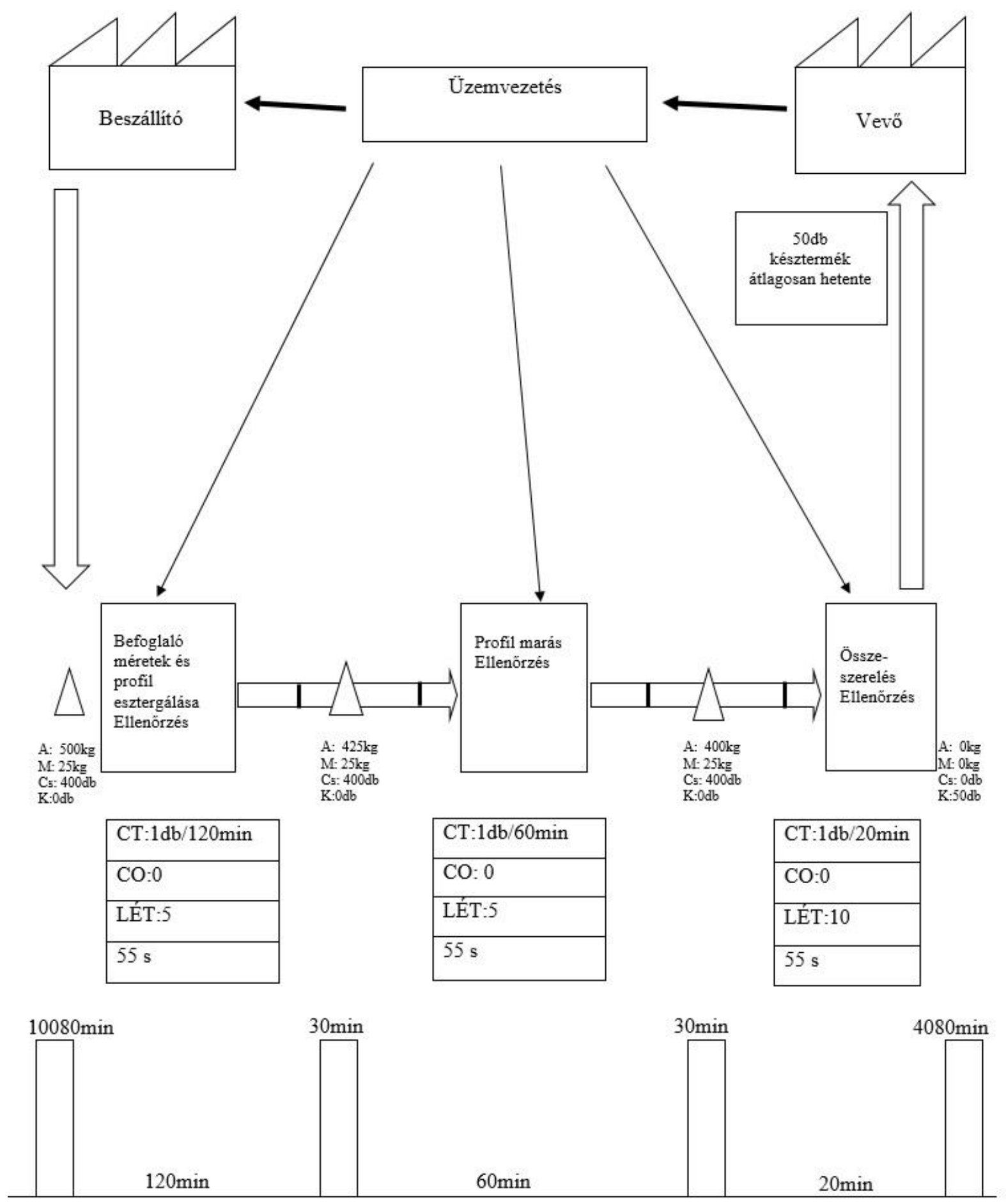

$$
\text { Összesen: } \frac{14220 \mathrm{~min}}{200 \mathrm{~min}}
$$

4. ábra: Jövőállapotot szemléltető térkép

Forrás: Saját szerkesztés, 2020 


\section{4. Összefoglalás}

Tanulmányunkban megvizsgáltunk egy CNC fém forgácsoló üzem autó alkatrész gyártó tevekénységéhez szükséges rendszert. Ezen rendszert összehasonlítottuk a lean eszközök és módszerek alkalmazása előtti állapotot és a bevezetés utáni állapotot. A szemléltetés illetve a elemzés módszertana a Value Stream Mapping alkalmazásával történt. A jelen és jövő állapot összehasonlítása az alábbi táblázatban látható.

\section{Táblázat: Összefoglaló táblázat}

\begin{tabular}{|l|l|l|l|}
\hline & \multicolumn{1}{|c|}{ Jelenállapot } & \multicolumn{1}{c|}{ Jövőállapot } & \multicolumn{1}{c|}{ Eltérés } \\
\hline Teljes átfutási idő & $20520 \mathrm{~min}$ & $14220 \mathrm{~min}$ & $6300 \mathrm{~min}$ \\
\hline Értékteremtő idő & $250 \mathrm{~min}$ & $200 \mathrm{~min}$ & $50 \mathrm{~min}$ \\
\hline Átállási idő & $30 \mathrm{~min}$ & $0 \mathrm{~min}$ & $30 \mathrm{~min}$ \\
\hline Selejt & $5 \%$ & $2 \%$ & $3 \%$ \\
\hline Kezdő készlet & $1000 \mathrm{Kg}$ & $500 \mathrm{Kg}$ & $500 \mathrm{Kg}$ \\
\hline Létszám & 30 fő & 20 fő & 10 fő \\
\hline
\end{tabular}

Forrás: Saját szerkesztés, 2020

Az 1. táblázatból fontosnak tartjuk kiemelni az értékteremtő idő 250-200-percre való csökkenését. Ezen kívül a létszám csökkenés az amit az üzemvezetés a legjelentősebb változásnak tart. A módosításokat követően 10 fővel kevesebb ember dolgozik ezeken a rendszerben. Viszont fontos megemlíteni, hogy ezen emberek nem elbocsátva lettek a szervezettől, hanem munkaerejüket más tevékenységek során hasznosította a szervezet. Ezen kívül jól látható a változás szinte minden területen valamint a szervezeti kultúrában is érezhetővé vált a lean filozófia megjelenése.

További kutatási lehetőségek mind szervezeten belül és mind szervezeten kívül lehetségesek. Komplex ellátási láncon végig menő VSM elemzés rámutathatna a különböző hálózati pontok közötti mudákra amelyek kiküszöbölésével nem csak a szervezezek hanem maga az ellátási lánc is hatékonyabban tudna múködni. Ezen kívül érdemes lehetne egy szervezeti kultúra kutatást is lefolytatni a vállalkozás múködésében amellyel a menedzsment információhoz juthatna a lean filozófia beépüléséről a szervezeti kultúrába. Kutatásunk során megpróbáltunk rávilágítani kvalitatív esettanulmány révén hogy a kis-és közép vállalkozások folyamataiban is hatékonyan alkalmazhatóak és implementálhatóak a lean eszözök és módszerek.

\section{Irodalomjegyzék}

[1] Demeter K. - Jenei I. - Losonci D. (2011): A lean menedzsment és a versenyképesség kapcsolata, Budapesti Corvinus Egyetem Versenyképesség Kutató Központ, Budapest.

[2] Faulkner W. - Badurdeen F. (2014): Sustainable Value Stream Mapping (Sus-VSM): methodology to visualize and assess manufacturing sustainability performance, Journal of Cleaner Production. Vol 85. No: 8-18. p.

[3] Gyenge B. - Kozma T. - SZILÁGYI H. (2015): Lean menedzsment alkalmazása szolgáltatóvállalat esetében, Vezetéstudomány, Budapesti Corvinus Egyetem, Budapest, Vol 4. No: 44-54. p.

[4] Haefner B. et al. (2014): Quality Value Stream Mapping, Procedia CIRP. - Netherlands: Elsevier, Vol 17. No: 254259. p.

[5] Halászné E. (1998): Sips Logisztika, Logisztikai Fejlesztési Központ Magyar Világ Kiadó, Budapest.

[6] Hines P. - Rich N. (1997): The seven value stream mapping tools, International Journal of Operations \& Production Management, Vol 1-2. No: 46-64. p.

[7] Kosztolányi J. - Schwahofer G. (2012): Lean alapok, KaizenPro Oktató és Tanácsadó Kft, Budapest.

[8] Kosztolányi J. - Schwahofer G. (2012): Értékfolyamat térképezés, Kaizenpro Oktató és Tanácsadó Kft, Budapest.

[9] Körmendi L. - Pucsek J. (2008): A logisztika elmélete és gyakorlata,Saldo Pénzügyi Tanácsadó és Informatikai Zrt, Budapest.

[10] Liker J. K. (2004): The Toyota Way, CWL Publishing Enterprises Inc,. New York.

[11] Losonci D. (2017): Lean menedzsment, in: Termelés, szolgáltatás, logisztika, szerkesztette: Demeter K., Wolters Kluwer Kft, Budapest Vol 2.

[12] Marodin G. et al., (2018): Lean product development and lean manufacturing: Testing moderation effects, International Journal of Production Economics. - Netherlands: Elsevier, Vol 203. No: 301-310. p.

[13] Ohno T. (1988): Toyota Production System: Beyond Large-Scale Production, Productivity Press, New York.

[14] Rahani A. R. - Ashraf M. (2012): Production Flow Analysis through Value Stream Mapping: A Lean Manufacturing Process Case Study, Procedia Engineering, Vol 41. No: 2, 1727-1734. p. 
[15] Singh B. - Garg S.K. - Sharma K. (2011): Value stream mapping: literature review and implications for Indian industry, The International Journal of Advanced Manufacturing Technology, Vol 53. No: 799-809. p.

[16] Toarniczky A. et al., (2012): A lean kultúra értelmezése és mérése egy egészségügyi szolgáltatónál Vezetéstudomány, Budapesti Corvinus Egyetem, Budapest Vol 43. különszám No: 106-120. p.

[17] Womack J. P. - Jones D. T. (2003): Lean Thinking,:A Division of Simon \&Schuster, Inc, New York.

[18] Zéman Z. (2016): A kontrolling fejlődéstörténetének főbb irányzatai, Nyugat- magyarországi Kiadó, Gazdaság és Társadalom, Vol 8 No: 2, 77. p.

[19] Zsidai L. (2016): Integrált Gyártórendszerek FMS/CIM/LEAN, Fenyves Dent Kft, Gödöllő. 